\title{
Kepengaturan dan Penolakan Relokasi: Kasus Warga Watugajah Pascabencana Gunung Merapi Tahun 2011-2013
}

\author{
Lubabun Ni'am•
}

\begin{abstract}
After the 2010 Mount Merapi eruption, the people of Watugajah Village, Magelang District, Central Java Province, were conducted to relocate from their hometown. The resettlement programme was implemented as part of post-disaster governmentality means with birocratic rationality on disaster-prone zone. Governmentality is "an attempt to regulate people through calculated means" (Li, 2007: 275); "the techniques and procedures that undertakes to conduct individuals throughout their lives by placing them under the authority of a guide responsible for what they do and for what happens to them" (Foucault, 2003). Based on an empirical research in Watugajah and several secondary data from various sources (news and programme handbook), this article examines a research question: how the contestation among the actors in Watugajah happened to the case of the people's denial of the relocation in the context of Mount Merapi post-disaster? This article shows an inquiry that the denial is not a part of an antipathy to the governmental authority. Instead, people show both their self defence positioning to get the better life based on their own reason as well as their tactical positioning to be head-to-head with the programmes, aids, and the policies derived from various sides.
\end{abstract}

\section{Keywords:}

governmentality; the denial of resettlement; contestation among actors; Mount Merapi.

\begin{abstract}
Abstrak
Pascabencana Gunung Merapi 2010, warga Dusun Watugajah di Kabupaten Magelang, Jawa Tengah, diarahkan untuk relokasi. Relokasi diterapkan sebagai bagian dari strategi kepengaturan pascabencana dengan rasionalitas birokratis dan ilmiah tentang kawasan rawan bencana. Kepengaturan (governmentality) adalah "upaya untuk mengatur manusia dengan cara-cara yang terkalkulasi" (Li, 2007: 275); "teknik dan prosedur yang diterapkan dengan jalan menempatkan kehidupan individu-individu di bawah otoritas yang bertanggung jawab untuk mengarahkan apa yang mereka lakukan dan terjadi pada mereka" (Foucault, 2003). Warga Watugajah menolak skema relokasi. Berdasarkan penelitian lapangan di Watugajah dan data sekunder dari berbagai sumber (berita dan buku program), artikel ini hendak menjawab pertanyaan: bagaimana kontestasi di antara para aktor yang terjadi dalam kasus penolakan warga Watugajah terhadap relokasi pascabencana Gunung Merapi? Artikel ini menyajikan temuan bahwa penolakan warga bukanlah bentuk antipati terhadap otoritas kepengaturan. Warga justru menunjukkan gabungan antara sikap mempertahankan diri untuk kehidupan yang lebih baik menurut mereka, sekaligus bersikap taktis atas hadirnya program, bantuan, maupun kebijakan dari berbagai pihak.
\end{abstract}

\footnotetext{
- Editor INSIST Press

Email: lubabunniam@mail.ugm.ac.id
} 


\section{Kata kunci:}

kepengaturan; penolakan relokasi; kontestasi antaraktor; Gunung Merapi.

\section{Pendahuluan}

Bencana merupakan ancaman bagi kelangsungan hidup manusia. Tetapi, kerentanan dalam struktur komunitas manusialah yang memengaruhi besar atau kecilnya setiap paparan ancaman sebagai sebuah bencana. Sekalipun begitu, kerentanan tidak mengidap sedari lahir dalam diri manusia atau terkandung secara terberi pada lingkungan komunitas. Kerentanan tidak tiba-tiba jatuh dari langit (Ribot, 2010). Sebaliknya, tingkat kerentanan terbentuk oleh dimensi sosial, politik, dan ekonomi yang kompleks (Wisner et al., 2004) serta bertautan dari masa ke masa (Bankoff, 2004). Kerentanan dapat ditekan dalam rangka menciptakan profil masyarakat yang cepat dan selalu bangkit dari bencana. Teori umum dalam kajian bencana memberikan asumsi bahwa kerentanan dapat dikurangi seminimal mungkin dengan jalan memperkuat kapasitas masyarakat (lihat INSIST, 2012).

Argumentasi itulah yang selanjutnya memantik dorongan global untuk mengantisipasi ancaman bencana supaya tidak meluluhlantakkan capaian pem-bangunan dan modernisasi skala luas. Ide mengenai pengurangan risiko bencana berangkat dari kehendak ini sehingga mendorong berbagai aktor untuk menerapkan intervensi guna membangun masyarakat yang mempunyai seperangkat teknik untuk menyikapi bencana, baik pada fase sebelum, saat, maupun sesudah bencana (Twigg, 2009: 8). Seperangkat teknik untuk membangun kondisi masyarakat yang memiliki daya lenting terhadap bencana itulah yang dinamakan sebagai-meminjam cara pandang dari Foucault (1991) - upaya kepengaturan (governmentality).

Pemahaman terhadap praktik kepengaturan dalam bencana tidak bisa dilepaskan dari diskursus yang lebih besar, yakni pengurangan risiko bencana. Terlebih lagi, Indonesia yang karena sering dihantambencana, sekarang dianggap sebagai "supermarket bencana" (James, 2008: 426). Berkaitan dengan premis bahwa teknik kepengaturan adalah praktik kekuasaan, maka kepengaturan bencana pun layak untuk dilihat dalam suatu relasi kuasa bila mencermati betapa gejala ini tidak sama purbanya dengan kejadian bencana itu sendiri. Diskursus tersebut bergerak paralel dengan kampanye global tentang pengurangan risiko bencana. Manajemen penanggulangan bencana pun mengalami pemantapan yang berarti setelah terjadi sejumlah agenda global di tingkat regional maupun global (Hewitt, 1995; Tierney, 2012).

Pada sejumlah kawasan rawan bencana, kerangka diskursus tersebut diterapkan dalam praktik-praktik yang spesifik. Masyarakat di daerah yang ditetapkan sebagai kawasan rawan sehingga mengancam kehidupan komunitas, misalnya, diarahkan agar mempunyai rencana dan prosedur kesiapsiagaan. Mereka memetakan potensi kawasan masing-masing, membuat peta kawasan, membikin rencana kontijensi untuk setiap ancaman bencana, mempersiapkan tim relawan desa, dan sebagainya. Bagi komunitas yang terpapar oleh bencana sebelumnya, mereka "disuntik" dengan berbagai program pemulihan, pemberdayaan ekonomi, revitalisasi ruang budaya lokal yang khas, termasuk membangun kembali permukiman yang dianggap aman terhadap bencana. Mereka yang masuk dalam kawasan rawan bencana Gunung Merapi pada 2010, contoh, diarahkan untuk meninggalkan tempat tinggal semula. Seruan tersebut diarahkan pula pada warga Dusun Watugajah-dusun yang berada persis di tepi Jalan Raya Yogyakarta-Semarang di kawasan Kabupaten Magelang, Jawa Tengah. (Demi 
menghindari prasangka yang tidak perlu dan dalam rangka menjaga keberlanjutan kegiatan warga, nama "Watugajah" digunakan sebagai sebutan pengganti untuk nama dusun lokasi penelitian.)

Dampak dari bencana Gunung Merapi pada 2010 memang merasionalisasi penerapan program rehabilitasi dan rekonstruksi pascabencana bagi warga penyintas. Pemerintah pusat memutuskan sejumlah area yang terdampak langsung sebagai areal larang huni bagi warga. Kawasan Watugajah termasuk ke dalam kawasan zona merah limpasan lahar dingin Kali Putih, sehingga menjadi areal larang huni. Oleh karena itu, warga yang sebelumnya menetap di Watugajah-bukan hanya menetap, melainkan juga turun-temurun menghidupi lingkungan tersebut-diarahkan untuk relokasi. Relokasi bisa dilakukan secara mandiri maupun secara berkelompok dengan bantuan pemerintah dan prokurator proyek relokasi. Rencana relokasi itu hadir ke tengahtengah warga ketika mereka masih berada di lokasi hunian sementara. Kehadiran program relokasi diikuti dengan bergulirnya prasangka, rumor, dan pergolakan di internal warga.

Maka, begitu warga menolak relokasi dan terjadi kontestasi yang melibatkan berbagai aktor dan otoritas, analisis yang relevan adalah analisis tentang kepengaturan dari program bersangkutan, yakni relokasi atas warga Watugajah sebagai penyintas pascabencana. Analisis sosiologi untuk kepengaturan tidak bisa mengelak dari pembacaan atas kontestasi kuasa yang menghubungkan para aktor dalam kumparan kepengaturan. Perhatian analisis ini terletak pada "keragaman otoritas yang berusaha mengatur perilaku" dan "cara di mana kita (warga) sekarang dibentuk oleh konflik" (Rose, 2004: 21, tambahan dalam tanda kurung oleh penulis) dalam konteks penolakan relokasi. Oleh karena itu, artikel ini hendak menjawab rumusan masalah yang berbunyi: bagaimana kontestasi antaraktor yang terjadi dalam kasus penolakan warga Watugajah terhadap relokasi pascabencana Gunung Merapi pada 2010? Artikel ini membatasi cakupan data lapangan selama rentang 2011 hingga 2013. Tahun 2011 diambil sebagai batas awal penelitian ini karena pada tahun itulah, tepatnya pada Januari 2011, warga Watugajah terpaksa meninggalkan lokasi dusun, buntut dari limpasan lahar hujan Gunung Merapi. Batas akhir data penelitian ini adalah (akhir) 2013, dimana pengumpulan data mesti dicukup-kan setelah warga memutuskan untuk kembali menghuni kawasan dusun semula.

\section{Kepengaturan dan Relokasi}

Kepengaturan (governmentality) merupakan cara pandang yang diperkenalkan Michel Foucault pada 1970-an (Rose, O'Malley, dan Valverde, 2006: 83). Kepengaturan atau conduct of conduct (pengaturan perilaku) merupakan "upaya untuk mengatur manusia dengan cara-cara yang terkalkulasi" (Li, 2007: 275). Foucault (2003) melihat kepengaturan secara luas sebagai teknik-teknik dan prosedur yang diterapkan "dengan cara menempatkan kehidupan individu-individu di bawah otoritas yang bertanggung jawab untuk mengarahkan apa yang mereka lakukan dan apa yang terjadi pada mereka". Kepengaturan merupakan "rangkaian taktik yang beragam" yang dimaksudkan untuk menggapai "serangkaian hasil akhir yang spesifik" (Foucault, 1991: 95).

Menurut Li (2007: 276):

\begin{abstract}
"Intervensi program kepengaturan itu penting untuk diperhatikan karena membuahkan suatu dampak. Tetapi, intervensi kepengaturan itu jarang membentuk dunia baru yang sesuai dengan perencanaan, meski intervensi itu memang mengubah sesuatu. Intervensi itu mungkin ditentang, tetapi penentangan itu tidak berasal dari posisi atau matriks di luar bidang kekuasaan."
\end{abstract}

Pada titik ini, kekuasaan untuk mengatur membentuk dikotomi antara kekuasaan itu 
sendiri dan penentangan terhadapnya (counterconduct); "antara program dan kegagalannya, antara tindakan dan penentangan terhadap tindakan tersebut" (Rose, 2004: 21). Oleh karena itu, subjek dalam intervensi kepengaturan harus dibentuk, diposisikan, dan dipersepsikan secara berbeda. Proses pembentukan subjek ini abai bahwa hal itu bukanlah "proyek yang mulus dan sempurna, melainkan secara inheren mengandung karakteristik konflik, kontestasi, dan kekacauan" (McKee, 2009: 474). Bahkan, tidak sebatas ketika praktik kepengaturan sudah diterapkan, "pada saat program kepengaturan dinyatakan, seketika itulah kontestasi sudah menjadi perwujudan nyatanya" (van Baar, 2011: 14) karena "relasi terkait kontestasi (...) itu melekat dalam diri sang pengatur" (O'Malley et al., 1997 dalam van Baar, 2011: 14). Dengan demikian, praktik kepengaturan tidaklah homogen dan menyegala sehingga dalam dirinya melekat batas-batas.

Ada empat batasan praktik kepengaturan (Li, 2007: 276-277). Pertama, kekuasaan itu mengarahkan individu bertindak untuk melakukan sesuatu sehingga kekuasaan tidak sama dan tidak bekerja dengan kekerasan atau cara-cara totalitarian yang lain. Kedua, populasi yang menjadi target kepengaturan beririsan dengan interaksi sosial dan latar kesejarahan tertentu yang rumit dan berada di luar jangkauan perencanaan. Oleh karena itu, pengatur perlu menghadirkan konjungtur yang spesifik untuk mewadahi intervensinya. Keberadaan populasi ini, bagi Foucault (1991: 95), sangat krusial karena tampil di atas segalanya sebagai tujuan akhir dari pengaturan. Ketiga, intervensi kepengaturan mengandung risiko akan lahirnya dampak yang bisa kontradiktif sehingga program kepengaturan yang diterapkan akhirnya jadi sia-sia bahkan kontraproduktif. Keempat, adanya ketegangan tertentu antara rasionalitas untuk mengatur dan tindakan untuk mengkritiknya. Jadi, sebenarnya tidak pernah ada istilah menerima atau menampung kritik, yang ada justru sebaliknya: depolitisasi yang efektif terhadap realitas konflik pada ranah implementasi kepengaturan.

Secara khusus, artikel ini menilik kepengaturan relokasi pascabencana, yang sejatinya diturunkan dari diskursus tentang pengurangan risiko bencana, serta pengaruhnya terhadap warga Watugajah yang sebagian tidak mau dan sebagian mau pindah dari lokasinya semula. Dengan demikian, artikel ini menjadi "refleksi dan komentar atas diskursus" (Abrahamsen, 2000) pengurangan risiko bencana dalam bentuk kepengaturan relokasi. Artikel ini bukan penilaian yang umum tentang, misalnya, modal sosial dalam membangun komunitas yang tangguh terhadap bencana (cf Kusumasari dan Alam, 2012; Saragih et al., 2014). Artikel ini menggali dampak yang menyembul dan dipertarungkan warga Watugajah sebagai strategi dekonstruksi yang tumbuh "mengikis, memaparkan, membuat rentan, dan memungkinkan terhambatnya" (Foucault, 1978: 100-101, 2008: 130-131) kepengaturan relokasi.

Dalam konteks pascabencana, relokasi merupakan salah satu program pembangunan yang terdapat dalam rangkaian kegiatan rehabilitasi dan rekonstruksi pascabencana. Artikel ini sependapat dengan Bauman (dalam Oliver-Smith, 2002: 2): relokasi adalah "perwujudan nyata dari ambisi perekayasaan yang dilakukan oleh negara, yang di dalamnya mengandung unsur adanya monopoli negara dalam mengelola kekuatan paksaan, relatif tak bertentangan dengan bentuk kekuasaan nonpolitik dan institusi-institusi yang mengurus persoalan sosial lain, serta mampu melakukan kontrol terhadap lokasi orang dan objek-objek yang ada di dalamnya". Oleh karena itu, "orang yang direlokasi merupakan cerminan dari kondisi ketidakberdayaan sebagai korban karena dari situlah dia kehilangan kontrol atas ruang secara fisik" (Oliver-Smith, 2002: 2), serta tercerabut dari nilai-nilai sosial, budaya, dan 
ekonomi yang melekat di sebalik ruang fisik tersebut.

\section{Relokasi Pascabencana Gunung Merapi}

Relokasi korban bencana letusan Gunung Merapi 2010 adalah bagian dari proyek yang dipegang oleh kelembagaan yang bekerja dalam kegiatan rekonstruksi pascabencana gempa bumi di D.I. Yogyakarta, Jawa Tengah, dan Jawa Barat, lalu letusan Gunung Merapi 2006. Kelembagaan yang merupakan prokurator yang dimaksud adalah proyek Rekonstruksi dan Rehabilitasi Masyarakat dan Permukiman Berbasis Komunitas (Rekompak). Proyek tersebut dirancang sebagai bagian dari strategi rekonstruksi pascabencana hasil kerjasama Pemerintah Indonesia dan Bank Dunia. Salah satu buku acuan tentang proyek rekonstruksi adalah buku yang diterbitkan Bank Dunia berjudul Safer Homes, Stronger Communities: A Handbook for Reconstructing after Natural Disasters (Jha et al., 2010).

Sedarinama proyek, pendekatan "berbasis komunitas" memang tampak eksplisit. Ada promosi bahwa proyek rehabilitasi dan rekonstruksi pascabencana digarap dengan konsep partisipatif. Pendekatan ini menegaskan pendapat Sliwinski (2010: 177) bahwa rekonstruksi pascabencana tidak dapat dilepaskan dari konsep "partisipasi komunitas"; pekerja bencana berperan dalam merancang dan menjalankan proyek-proyek yang menekankan pelibatan masyarakat. Davidson et al. (2007: 101) mengutarakan pandangan serupa: "literatur-literatur kontemporer mengenai pelaksanaan proyek permukiman, termasuk proyek rekonstruksi pascabencana, mengkaji seputar paradigma yang telah diterima secara luas sebagai partisipasi komunitas".

Narasi besar tersebut juga tertulis dalam dokumen berjudul Proyek Rehabilitasi dan Rekonstruksi Masyarakat dan Permukiman Berbasis Komunitas Pascaerupsi Gunung Merapi 2010: Pedoman Operasional Umum (2011). Dalam buku itu disebutkan bahwa pendekatan
Rekompak adalah “pemberdayaan masyarakat dengan mengedepankan perpaduan antara pembangunan bertumpu pada kelompok masyarakat dan pembangunan bertumpu pada nilai" (2011: 4). Itu berarti, ada dua tumpuan atau poros dalam pembangunan. Pertama, kelompok masyarakat. Ini berarti "mendudukkan masyarakat sebagai pelaku utama yang dipercaya mampu mengambil keputusan penting menyangkuthidup mereka". Oleh karena itu, mereka dianggap memiliki kapasitas untuk terlibat dalam upaya pemulihan permukiman, "dengan pendampingan yang tepat" (2011: 4). Kedua, nilai. Melalui proyek pembangunan permukiman pascabencana, masyarakat diharapkan bisa mengembangkan "nilai-nilai luhur seperti saling percaya, gotong royong, dan lain-lain untuk menumbuhkan kembali kapital sosial" (2011: 4).

Tentu saja, proyek relokasi ini bukan tidak mengubah sesuatu: ada hunian baru bagi warga korban bencana Gunung Merapi pada 2010. Sebelum bencana tersebut terjadi, lewat mekanisme Java Reconstruction Fund (JRF), telah dibangun 15.000 rumah tahan gempa di Jawa. Setelah itu, dari dana Pemerintah Indonesia sendiri, dibangun 200.000 rumah dalam waktu kurang dari dua tahun (Sekretariat Multi Donor Fund untuk Aceh dan Nias dan Java Reconstruction Fund, 2012). Untuk rekonstruksi pascabencana Gunung Merapi pada 2010, hingga November 2012, tercatat 1.305 rumah telah dibangun, 452 rumah dalam proses pembangunan fisik, dan 378 rumah dalam masa persiapan untuk dibangun (Layang PRB, Oktober-November 2012). Sekalipun terlihat adanya capaian impresif, intervensi berwujud proyek permukiman pascabencana Gunung Merapi sulit untuk dijadikan sebagai klaim atau tidak begitu saja menjadi cermin dari partisipasi warga dalam membangun komunitas baru yang tangguh terhadap bencana.

Terhadap korban penyintas Gunung Merapi pada 2010, peran dari prokurator 
adalah "memfasilitasi pembangunan rumah tahan gempa dengan merelokasi warga ke daerah yang dinyatakan aman untuk dihuni berdasarkan peta kawasan rawan bencana Gunung Merapi yang dikeluarkan oleh Badan Geologi Kementerian Energi dan Sumber Daya Mineral" (Direktorat Jenderal Cipta Karya, 2011: 36). Arahan untuk relokasi inilah yang tidak bisa diterima oleh semua warga di lereng Gunung Merapi. Pada awal ide tersebut mengemuka, yakni tatkala warga mulai jenuh tinggal di hunian sementara dan sebagian mulai balik ke tempat tinggalnya semula, di sejumlah titik terdapat spanduk protes berbunyi: "Kami Butuh Renovasi, Bukan Relokasi", "Mengapa Kami Menolak Relokasi", dan "KRB: Kawasan Ra di-Bantu" (Jalin Merapi, 26 November 2010; 17 Juni 2011). Ungkapan protes itu dapat ditemui di Dusun Kalitengah Lor, Kalitengah Kidul, dan Srunen, ketiganya termasuk kawasan Desa Glagaharjo, Kecamatan Cangkringan, Sleman. Penolakan terhadap relokasi juga mengemuka dari sebagian warga Desa Pangukrejo, Kecamatan Cangringan, dan Dusun Watugajah.

\section{Nalar Tanding tentang Kawasan Rawan Bencana}

Seusai erupsi Gunung Merapi 2010, limpasan lahar hujan yang mengalir dari Kali Putih menerjang sebagian kawasan Watugajah, awal Januari 2011. Limpasan itu membawa material lumpur dan batu-batu raksasa dari puncak Gunung Merapi. Dua dari tiga kawasan rukun tetangga di dusun tersebut terempas oleh limpasan lahar hujan, yang merusak dan mengubur puluhan rumah warga. Oleh karena dampak lahar hujan itulah, beberapa waktu kemudian, warga diarahkan untuk relokasi, dalam arti meninggalkan dusun karena kawasan mereka dicap sebagai kawasan rawan bencana lahar hujan. Setelah rentetan peristiwa erupsi dan lahar hujan Gunung Merapi pada rentang akhir 2010 hingga awal 2011, setiap bentang 300 meter dari bibir sungai yang berhulu dari puncak dan lereng Gunung Merapi dinyatakan sebagai kawasan larang huni. Sesuai peta yang dikeluarkan Badan Geologi, Kementerian Energi dan Sumber Daya Mineral, Watugajah termasuk dalam Kawasan Rawan Bencana I. Di atas peta, Watugajah termasuk areal berwarna kuning, dengan penjelasan sebagai:

“(..) kawasan yang berpotensi terlanda
lahar/banjir dan tidak menutup
kemungkinan dapat terkena perluasan
awan panas dan aliran lava. (...)
Apabila terjadi lahar dalam skala besar,
warga masyarakat yang terancam agar
dievakuasi untuk mencegah korban
jiwa. Secara umum cara penyelamatan
diri adalah menjauhi daerah aliran
sungai dan menuju tempat evakuasi
yang aman. Sosialisasi dan pelatihan
penanggulangan bencana lahar perlu
dilakukan."

Kepala Dusun Watugajah mengakui bahwa kawasan dusunnya secara nalar memang masuk akal terkena limpasan lahar hujan. Pasalnya, daerah aliran Kali Putih yang melewati kawasan Watugajah sebelumnya dangkal, sempit, dan berkelok. Pada peristiwa bencana 2011, limpasan lahar hujan awalnya melewati jalan raya Yogyakarta-Semarang, kemudian masuk ke dusun bagian utara. Aliran lahar hujan menerabas kelokan, meluber ke luar badan sungai yang dangkal dan sempit. Material lahar hujan merangsek ke kawasan Watugajah hingga bentang 200 meter jika ditarik dari bibir Kali Putih.

Setelah itu, sesuatu yang disebut "nalar" pun bersifat dinamis menurut warga. Mereka menerima secara nalar kejadian 2011, tetapi juga memasang nalar tanding yang lain ketika sejumlah solusi kebijakan diterapkan oleh pemerintah: warga menganggap tidak lagi benar mengatakan kawasan dusun mereka sebagai kawasan berbahaya selayaknya kondisi 2011. Warga pun berani menolak arahan untuk relokasi justru karena pemerintah dianggap 
telah memberikan solusi dalam wujud pembangunan teknis. Cara mengambil sikap berdasarkan permainan nalar semacam ini tentu saja berbenturan dengan pertimbangan dalam logika penetapan kawasan rawan bencana, yang notabene dirumuskan secara ilmiah berdasarkan kejadian lahar hujan pada 2011 (lihat Aisyah dan Purnamawati (2012), Hidayat dan Rudiarto (2013), dan Putro (2011)).

Ada dua hal yang menjadi alasan yang masuk akal bagi warga untuk menolak relokasi. Pertama, pembuatan jembatan baru dan sungai yang sudah diperdalam dan diperlebar. Sebelum Watugajah terkena limpasan Kali Putih, sebuah jembatan besar sempat terempas sehingga memutus transportasi utama dari Magelang ke Yogyakarta. Tetapi, jembatan itu kini sudah dibangun kembali. Semua sungai yang tidak mampu menampung aliran lahar hujan pada 2011 juga diperdalam dan diperlebar, bahkan di beberapa bagian ditinggikan dengan tanggul yang kokoh. Di sejumlah titik di badan sungai juga didirikan sabo dam, yang dianggap mampu menahan laju aliran sungai sehingga debit dan arusnya tidak akan besar sesampainya di kawasan hilir pada bagian bawah. Kepala Dusun Watugajah berkata, andai program relokasi direalisasikan sebelum ada kebijakan tersebut, warga pasti bersedia untuk relokasi. Dengan begitu, tanpa ada program relokasi pun warga pasti akan pindah. Tetapi, karena sudah ada solusi berupa pembangunan teknis dari pemerintah, sebagian besar warga akhirnya balik ke Watugajah.

Kedua, kawasan Watugajah dianggap memiliki karakter yang berbeda dengan kawasan korban bencana yang lain, baik itu dibandingkan dengan kawasan di lereng atas Gunung Merapi maupun kawasan lain terdampak lahar dingin yang berada lebih jauh dari jalan raya antarprovinsi. Posisi Watugajah yang terletak persis di tepi jalan raya Yogyakarta-Semarang itulah yang menjadikan Watugajah dianggap memiliki karakter khusus yang berbeda dengan kawasan-kawasan lainnya. Kekhususan itu merujuk pada keberadaan jalan raya Yogyakarta-Semarang. Dalam persepsi warga, apabila terjadi sesuatu dengan jalan raya utama tersebut, pemerintah akan menyelamatkan akses jalan. Oleh karena itu, Watugajah pun tetap selamat dan menjadi bagian dari upaya penyelamatan tersebut.

Sekalipun demikian, pengalaman bencana telah membuat warga Watugajah berupaya lebih mempersiapkan diri untuk siaga terhadap bencana. Warga Watugajah membentuk tim siaga dari relawan-relawan setempat. Di tengah dusun, dipasang menara pemancar ulang handy talkie (HT). Mereka disokong oleh salah satu Lembaga Swadaya Masyarakat (LSM) dalam mengembangkan kapasitas tim siaga. Mereka melakukan simulasi seandainya terjadi bencana sehingga tahu cara yang benar untuk merespons ancaman. Sejumlah alat penyokong tim siaga hampir mencukupi: jalur evakuasi, titik kumpul, tandu, truk sebagai kendaraan evakuasi, megaphone, genset, repeater dengan frekuensi radio tersendiri, termasuk protokol tetap dan tugas pokok dan fungsi bagi personel tim siaga. Jadi, ada komitmen untuk menjadi dusun yang tangguh bencana (lihat Ascholani dan Padmono akan terbit). Keputusan untuk kembali ke Watugajah disadari bukan tanpa alasan dan bukan tindakan yang ngawur.

\section{Merawat Jejak Kesejarahan atas Ruang}

Pada November 2012, 20 kepala keluarga di Watugajah membangun rumah masingmasing di lokasi semula yang terdampak (Kedaulatan Rakyat, 8 November 2012). Sebulan berikutnya, sebagian besar warga tengah menempuh tahap-tahap akhir dalam membangun rumah. Salah satu warga, semisal, telah membangun rumah dengan dana sendiri sekitar 60 juta rupiah (Seputar Indonesia, 24 September 2012). Bagi dia, yang tinggal bersama istri dan tiga anak, Watugajah adalah tanah leluhur keluarga sehingga tidak ada alasan untuk tidak menghidupi kembali tanahnya. 
Apalagi, makam mertua terletak tidak sampai sepelemparan bola dari rumahnya. Watugajah, bagi warga setempat, telah menorehkan latar kesejarahan yang panjang jejaknya. Pada konteks ini, relokasi berarti upaya pihak luar untuk menghapus jejak mereka di tanah sendiri. Bencana merupakan bagian dari sejarah itu sendiri, yang turut merawat ingatan sosial dari generasi ke generasi.

Sementara itu, bagi warga yang lain, dia dan keluarga enggan pindah dari Watugajah karena sang suami bekerja sebagai penambang pasir yang lokasi penambangannya ada di sekitar Watugajah (Kompas, 25 Oktober 2012). Program untuk memindahkan keluarga ini dari Watugajah berarti tindakan yang memperberat sebuah keluarga untuk tetap bertahan sehariharinya. Ketika limpasan lahar hujan sudah meninggalkan tahapnya sebagai bencana, tentu janggal untuk menerima upaya relokasi yang dapat menjauhkan seseorang dari sumber penghasilan. Bagi warga yang bekerja sebagai penambang pasir dan pengolah batu, seperti dinyatakan warga yang lain, bahwa kalau tidak ada luncuran lahar hujan, malah membuat orang Watugajah merana.

Dari sini tersirat bahwa bencana lahar hujan bukanlah sesuatu yang baru bagi warga Watugajah. Sejauh ingatan warga, Watugajah pernah diterjang bencana limpasan lahar hujan pada 1969. Seorang warga masih mengingat kisah dari orangtuanya tentang limpasan lahar dingin pada 1969. Ketika itu, kawasan RT 01 terpapar lahar hujan. Rumah-rumah warga masih berdiri dengan bahan papan kayu. Warga Watugajah yang kehilangan rumah, sama seperti respons warga atas bencana lahar hujan pada 2011, kembali membangun hunian di lokasi semula. Dia menuturkan bahwa harta benda selalu bisa dicari kembali.

Sementara itu, pada kejadian bencana 2011, hampir semua bagian rumah warga sudah bermaterial batako atau batu bata alias rumah dengan dinding tembok. Artinya, tidak ada kelemahan dari segi bangunan, sebagaimana terjadi pada bencana pada 1969. Hanya, tinggi dan meluasnya kerusakan pada bencana 2011 itu lebih dikarenakan oleh material luncuran, terutama batu-batu, yang berukuran besar-besar sehingga bangunan apa pun tidak mungkin bisa menahannya. Sementara kini, dalam pemahaman warga, material vulkanis yang masih tersimpan di perut gunung sudah muntah banyak. Di perut gunung, material vulkanis sisa letusan pada 2010 sudah lebih berkurang untuk membentuk lagi luncuran lahar sehebat sebelumnya. BNPB (2011) memperkirakan, baru seperempat dari total 140 juta meter kubik material hasil erupsi Gunung Merapi pada 2010 yang dialirkan melalui lahar hujan. Lahar hujan diprediksi terus terjadi selama 3-4 tahun berikutnya.

Semua itu menjadi sebentuk pengetahuan yang direproduksi orang-orang Watugajah berdasar persentuhan dengan latar kesejarahan diri atas ruang dan rencana relokasi yang menghampiri mereka. Bahwa sikap yang diambil warga untuk tetap tinggal di Watugajah berarti tidak tunduk pada arahan supaya relokasi, hal itu menunjukkan bahwa proses dan pengetahuan sosial berhasil membentuk preferensinya sendiri. Bahkan, untuk mengatakan warga Watugajah memiliki sikap menolak secara utuh pun tidaklah tepat. Bahwa terdapat penolakan relokasi, itu memang benar, bahkan terjadi pada sebagian besar warga. Sampai September 2012, tercatat 64 kepala keluarga sudah menerima proyek relokasi, sementara 106 kepala keluarga yang lain menolak relokasi. Sebagian warga Watugajah mengikuti program relokasi. Sebagian mengikuti relokasi, tetapi tetap menempati rumah di Watugajah yang dianggap masih patut ditinggali. Kepala Dusun Watugajah berujar bahwa warga tidak pernah menolak hunian tetap, hanya menolak relokasi.

\section{Kontestasi Kuasa dalam Penolakan Relokasi}

Dalam sebuah kesempatan audiensi dengan Badan Penanggulangan Bencana Daerah (BPBD) Magelang, warga Watugajah mendapat 
informasi bahwa orang-orang yang menolak relokasi tidak akan mendapatkan bantuan kebencanaan apa pun dari pemerintah, kecuali fasilitas kesehatan dan pendidikan. Listrik juga tidak akan difasilitasi PLN. Untung, warga Watugajah sudah mengurus listrik sebelum ada program relokasi. Listrik masih terpasang di Watugajah sampai masa penelitian. Tidak ada pemutusan listrik setelah ada ancaman yang diterima langsung oleh warga dalam kesempatan audiensi. Pada Oktober 2012, salah satu staf BPBD Magelang mengatakan bahwa pihaknya masih terus membuka kesempatan bagi warga yang berada dalam kawasan rawan bencana erupsi dan lahar dingin untuk mengikuti relokasi (Kompas, 22 Oktober 2012). Memang terdapat persimpangan yang tanpa titik temu antara warga dan pihak yang memegang otoritas kebijakan. Persimpangan itu memperlihatkan basis argumentasi dari masing-masing pihak berdasarkan kewenangan dan otoritas institusi.

Persimpangan itu tampak dari dua kasus terkait program relokasi Watugajah. Pertama, terkait dengan rencana relokasi. Pada Januari 2011, sudah ada pemikiran untuk menerapkan program relokasi bagi warga Watugajah. Hanya saja, saat itu masih dalam tahap pemikiran dan penyelarasan antara berbagai institusi, seperti Pemerintah Kabupaten Magelang, BNPB, dan Balai Penyelidikan dan Pengembangan Teknologi Kegunungapian (BPPTK). Pada awal 2011, Sekretaris Daerah Kabupaten Magelang mengatakan bahwa rencana relokasi masih sebatas wacana dan kajian terhadap wacana itu membutuhkan waktu lama, yakni dua hingga tiga tahun (Suara Merdeka, 7 Januari 2011). Dalam konteks mitigasi bencana, hasil kajian mereka diarahkan untuk menghasilkan pengaturan yang terbaik, dalam arti sesuai dengan kondisi dan ancaman yang dihadapi warga Watugajah. Penekanan pada faktor "ancaman" lahar hujan sebenarnya sudah memperlihatkan ke mana kepengaturan mengarah, yang akan dipaparkan di bawah.
Di muka sudah disebutkan, dari perspektif warga, preferensi untuk kembali ke Watugajah bukanlah berdasar pada faktor ancaman.

Yang jelas, terdapat ketakutan dari warga Watugajah akan kehilangan tanah. Tidak ada warga yang mau relokasi jika mereka harus melepas tanah yang mereka warisi dari generasi ke generasi. Sejumlah warga yang kemudian mengambil hunian tetap, meskipun belum tentu relokasi, dianggap sebagai warga yang melunak karena mereka sudah mendapat kepastian bahwa negara tidak akan mengambil tanah (Suara Merdeka, 30 April 2012). Warga tetap memiliki tanah karena, dalam pembangunan hunian tetap, tidak ada fase pengalihan status tanah semula sang penerima huntap (Suara Merdeka, 8 Februari 2012). Pada Juni 2012, 33 kepala keluarga mendaftar ke pemerintah desa untuk mendapat hunian tetap. Kepala desa menyebutkan bahwa pelunakan sejumlah warga itu disebabkan ada jaminan bahwa tempat tinggal mereka tetap menjadi hak warga, meski menerima hunian tetap (Kedaulatan Rakyat, 8 April 2012). Bagi kepala desa, faktor yang memicu "keberhasilan" tersebut adalah adanya "komunikasi yang baik" antara DPRD dan pemerintah desa mengenai kepastian hak milik atas tanah bagi warga Watugajah.

Pada kasus lain terkait tanah, "komunikasi yang baik" itulah yang dicurigai warga yang menolak relokasi. Kepala Dusun Watugajah mengatakan, dari peta tata ruang yang ada di balai desa, kawasan Watugajah merupakan kawasan yang diproyeksikan sebagai terminal kargo atau peti kemas. Meski isu tersebut segera dibantah Kepala BPBD Magelang (Seputar Indonesia, 24 September 2012), bantahan itu muncul belakangan setelah warga mencurigai rencana tata ruang Pemerintah Kabupaten Magelang yang tidak dikabarkan kepada warga. Salah satu warga Watugajah berkata bahwa ia tidak rela lahannya dikuasai oleh pihak lain, termasuk untuk pembangunan terminal kargo (Seputar Indonesia, 24 September 2012). Dia menyimpulkan, mencuatnya isu pembangunan 
terminal peti kemas menunjukkan bahwa pemerintah tidak bisa berlaku transparan kepada warga. Kecurigaan yang terbentuk sebagai pengetahuan tanding versi warga tidak dapat ditangkis hanya dengan bantahan. Usai warga Watugajah balik ke dusun, hingga masa penelitian, tidak ada aktivitas pembangunan terminal peti kemas di titik mana pun di lokasi yang ditetapkan sebagaimana tercantum dalam Pasal 51 ayat (5) Peraturan Daerah Nomor 5 Tahun 2011 tentang Rencana Tata Ruang Wilayah Kabupaten Magelang Tahun 2010-2030.

Kedua, tercermin dalam rapat DPRD Magelang bersama perwakilan warga Watugajah, BPPTK, BPBD Magelang, Rekompak, Balai Besar Wilayah Sungai Serayu-Opak (BBWSSO), dan dinas lain yang terkait di Gedung DPRD Magelang pada Rabu, 23 Mei 2012 (Tribunnews, 23 Mei 2012; Seputar Indonesia, 24 Mei 2012). Sebulan sebelum menggelar audiensi tersebut, Ketua DPRD Magelang mengadakan kunjungan lapangan ke Watugajah (Suara Merdeka, 30 April 2012). Pada kesempatan itu, Kepala Dusun Watugajah berkata bahwa seharusnya ada kelonggaran dari pemerintah terkait dengan hunian kembali warga yang berada dalam radius 300 meter dari tepi Kali Putih. Sang pejabat menanggapi hal itu sebagai permintaan warga dan akan mengawal permintaan warga supaya dikabulkan oleh pemerintah. Pada sesi rapat audiensi bulan berikutnya, pejabat yang bersangkutan memimpin rapat dan membiarkan "kawalan" dia atas permintaan warga ditelan oleh rekomendasi agar Watugajah dikosongkan, sesuai dengan pemaparan ilmiah dan birokratik dari BPPTK dan BBWSSO. Kunjungan dan audiensi bersama warga menjadi instrumen "depolitisasi yang efektif" (Li, 2007: 277) atas penolakan warga untuk menerima program relokasi dari Watugajah.

Berdasarkan Surat Gubernur Jawa Tengah Nomor 360/18319 tertanggal 20 September 2012, di Kabupaten Magelang, hanya 426 keluarga dari 746 keluarga yang bersedia relokasi dan
319 keluarga menolak meninggalkan tempat asal mereka (Sindonews, 24 Oktober 2012), sebagian di antaranya adalah warga Watugajah. Ketika itu, di Kabupaten Temanggung saat kunjungan dinas di Subterminal Agribisnis Soropodan, yang berarti tidak di hadapan warga penyintas Gunung Merapi secara langsung, Gubernur Jawa Tengah mengatakan tidak akan bertanggung jawab terhadap warga yang menolak relokasi apabila suatu waktu ke depan terkena bencana. Gubernur menganggap bahwa orang-orang yang menolak relokasi harus bertanggung jawab terhadap segala konsekuensi dan risiko yang harus ditanggung oleh karena keputusan yang diambil mereka sendiri (Kompas, 25 Oktober 2012).

\section{Di Sebalik Relokasi: Analisis Kepengaturan}

Mempromosikan pendekatan berbasis komunitas, relokasi terhadap warga penyintas bencana Gunung Merapi 2010 tidak layak disebut sebagai upaya paksaan, apalagi merupakan instrumen kekerasan. Relokasi itu intervensi etis yang mengarahkan warga untuk menjauh dari ancaman alam serta dilengkapi arahan untuk memperkuat kelembagaan dan kapasitas kesiapsiagaan warga atas ancaman serupa sebelumnya dan ancaman lain-lain yang potensial ke depan. Intinya, relokasi adalah praktik kepengaturan yang terkalkulasi. Pada titik inilah, relokasi sebagai strategi kepengaturan berjumpa pada batas-batas yang tidak terelakkan. Di sebalik penolakan relokasi warga Watugajah, artikel ini merumuskan empat poin pemikiran generik tentang intervensi kepengaturan pascabencana.

Pertama, kepengaturan relokasi warga Watugajah dapat menjadi kasus menarik untuk melacak dan memikirkan ulang definisi dan karakteristik "negara". Pada titik ini, "negara" sedari awal didetailkan dengan istilah lain seperti "rezim pengatur", "aparatus birokrasi", atau "kebijakan pemerintah"; bahwa "negara" bukanlah entitas fakta itu sendiri, melainkan klaim (Abrams dalam 
Li, 2005: 385). Mitchell (dalam Li, 2005: 385) turut mengarahkan supaya kita menaruh perhatian pada "praktik kepengaturan modern yang menghasilkan kekuatan yang nyata dari negara dan keterpisahannya dari masyarakat". Relokasi warga Watugajah tidak dapat diingkari merupakan teknikteknik yang diproduksi oleh institusi negara modern dan penyokongnya dalam rangka mengatur warga. Teknik kepengaturan melalui relokasi telah menunjukkan bagaimana "negara" menjadi entitas berbeda dari warga. Untuk menguatkan pentingnya relokasi dan memahamkannya kepada warga, negara mendayagunakan otoritas dan kewenangan untuk mengklaim kebenaran dari sebuah tindakan yang mestinya diambil oleh warga. Negara hadir sebagai ide dengan klaim yang membenarkan kebijakannya.

Kedua, aktor dan otoritas serta kepakaran dan spesifikasi masing-masing dalam praktik pengurangan risiko bencana, program rehabilitasi dan rekonstruksi pascabencana, termasuk proyek relokasi, itu beragam. Khusus pada kasus Watugajah, penulis melihat para aktor yang sesungguhnya berbeda peran, otoritas, narasi-narasi etis yang dipromosikan, dan batasannya masing-masing. Untuk relokasi, Rekompak mendapati peran tersendiri sebagai prokurator proyek. Dalam praktiknya, prokurator bersentuhan dengan beragam institusi seperti kepala dusun, kepala desa, gubernur, BPBD, BPPTK, LSM, BBWSSO, DPRD, termasuk warga itu sendiri. Narasi yang mencuat dari masing-masing aktor telah membentuk relokasi menjadi formasi diskursif tersendiri yang tidak tuntas, retak, dan terus berjalan. Dengan demikian, sulit untuk melacak visi kepengaturan yang utuh dan tunggal. "Semua itu dibentuk dalam relasi kuasa," kata Li (2005: 386), sehingga formasi diskursif mereka memberi tekstur pada kompleksitas kontestasi antaraktor.

Ketiga, peta kawasan rawan bencana mampu mendasari kebijakan relokasi warga yang masuk sebagai kawasan rawan bencana. Dari situlah narasi tentang "bagaimana kekuasaan bekerja untuk mendasari ruang yang berbeda dan bagaimana perencanaan terhadap ruang tersebut menghasilkan dampak terhadap kekuasaan" (Li, 2005: 385) ditelisik. Peta tersebut membentuk suatu kawasan menjadi berbeda-beda, yakni menjadi kawasan rawan bencana, sehingga membuatnya distingtif terhadap kawasan lain yang bukan kawasan rawan bencana. Penolakan relokasi dari warga Watugajah tidak berada di luar matriks di mana kekuasaan untuk mengatur mendapatkan legitimasi. Li (2005: 385) menyebutkan: "penolakan muncul dari dalam matriks ini dan merespons dalam beragam ranah kekuasaan". Warga Watugajah tidak hanya menjadi kelompok yang menolak relokasi, tetapi juga menjadi kelompok yang merepresentasikan diri sebagai pihak yang diancam, dibohongi, dan mengupayakan sendiri kebutuhan dalam rangka memperbaiki kehidupan pascabencana.

Keempat, penolakan warga bukanlah bentuk antipati terhadap otoritas kepengaturan. Dalam konteks pascabencana Gunung Merapi, selalu dapat ditemui semacam harapan akan perhatian melalui program pemerintah dan ungkapan-ungkapan syukur dan terima kasih kepada pihak-pihak lain seperti LSM yang telah memberikan pendampingan. Karena warga aktif dalam formasi diskursif kepengaturan pascabencana, mereka kerap menempatkan diri sebagai subjek yang tidak bermaksud untuk menepis keterlibatan dalam segalanya yang lain. Warga Watugajah terbukti masih terlibat dalam menyiapkan tim siaga, sekalipun mereka menolak relokasi. Tidak hanya di Watugajah, kasus Dusun Kalitengah Lor, Kalitengah Kidul, dan Srunen juga menunjukkan karakter yang serupa. Sebagian dari warga dusun-dusun itu tetap tinggal di kawasan yang merupakan kawasan rawan bencana, tetapi jengkel dengan sikap dari otoritas pemerintah yang mengecam tindakan mereka. Mereka tetap mengharap 
celah yang dapat mereka terima dan diberikan oleh pihak luar.

\section{Kesimpulan}

Dalam buku hasil pelaksanaan program relokasi, Rekompak mengklaim bahwa relokasi pascabencana Gunung Merapi menggapai sejumlah keberhasilan sesuai dengan pendekatan berbasis komunitas yang telah dicanangkan. Tetapi, dalam praktik di lapangan, kepengaturan dalam bentuk relokasi tidaklah sepenuhnya sesuai dengan prinsip berbasis komunitas. Salah satu fenomena yang tersembunyi dari balik klaim keberhasilan itu adalah adanya penolakan warga dari beberapa dusun untuk direlokasi, salah satunya warga Watugajah. Penolakan terhadap relokasi, selanjutnya, membukakan ruang kontestasi antara warga dan berbagai pihak. Warga berhadapan dengan beragam institusi yang memegang otoritas kepengaturan tersebut. Tetapi, penolakan warga Watugajah bukan antipati terhadap otoritas kepengaturan. Warga menunjukkan gabungan antara sikap mempertahankan diri untuk kehidupan yang lebih baik menurut mereka, sekaligus bersikap taktis - untuk tidak mengatakan pragmatisatas hadirnya sentuhan program, bantuan, maupun kebijakan dari berbagai pihak.

Semua itu merupakan respons terhadap semakin bertambahnya aktor dalam formasi diskursus pengurangan risiko bencana, yang berarti semakin menambah dalam dan kompleks relasi kuasa. Kasus Watugajah menunjukkan bahwa warga berada dalam formasi diskursus tersebut, bertarung dengan setiap program yang masuk, entah dalam bentuk penolakan maupun keretakan internal warga ketika berhadapan dengan relokasi. Di sini, secara khusus kasus Watugajah, tujuannya bukan hasil dari relokasi. Hasil dari relokasi bukan sesuatu yang esensial. Terhadap kasus Watugajah, tidak ada kisah yang akan berakhir, yang memuaskan semua pihak. Ini kontestasi yang tak pernah-dan tak akan-menjanjikan ketuntasan.

\section{Daftar Pustaka}

Abrahamsen, R. (2000). Sudut Gelap Kemajuan: Relasi Kuasa dalam Wacana Pembangunan. Yogyakarta: Lafadl Pustaka.

Aisyah, N. dan D.I. Purnamawati. (2012). “Tinjauan Dampak Banjir Lahar Kali Putih, Kabupaten Magelang Pasca Erupsi Merapi 2010." Jurnal Teknologi Technoscientia Vol. 5 No.1, hlm. 19-30.

Ascholani, C. dan S. Padmono. Akan terbit. "Pelaksanaan Kebijakan Desa/Kelurahan Tangguh Bencana: Jalan Masih Panjang." Wacana 31.

Van Baal, H. (2011). The European Roma: Minority Representation, Memory, and the Limits of Transnational Governmentality. Amsterdam: F\&N Eigen Beheer.

Badan Nasional Penanggulangan Bencana (BNPB). (2011). "Ancaman Lahar Dingin Merapi Terus Berlangsung." Pers rilis pada 29 April 2011 pukul 21.00 WIB.

Bankoff, G. (2004). "Time is of the Essence: Disasters, Vulnerability and History." International Journal of Mass Emergencies and Disasters Vol. 22 No. 3, hlm. 23-42.

Davidson, C.H., C. Johnson, G. Lizarralde, N. Dikmen, dan A. Sliwinski. (2007). "Truths and Myths about Community Participation in Post-Disaster Housing Projects." Journal Habitat International Vol. 31, hlm. 100-115.

Direktorat Jenderal Cipta Karya, Kementerian Pekerjaan Umum. (2011). Proyek Rehabilitasi dan Rekonstruksi Masyarakat dan Permukiman Berbasis Komunitas Pascaerupsi Gunung Merapi 2010: Pedoman Operasional Umum. Jakarta: Direktorat Jenderal Cipta Karya, Kementerian Pekerjaan Umum.

Foucault, M. (1978). The History of Sexuality, Volume I: An Introduction. New York: Pantheon Books.

. (1991). "Governmentality." Dalam The Foucault Effect: Studies in Governmentality with Two Lectures by and an Interview with Michel Foucault, disunting oleh G. Burchell, 
C. Gordon, dan P. Miller, 87-104. Chicago: The Chicago University Press.

. (2003). "Security, Territory, and Population."

Dalam The Essential Foucault: Selection from

Essential Works of Foucault, 1954-1984, disunting oleh P. Rabinow dan N. Rose, 259-261. New York dan London: The New Press.

.2008. Ingin Tahu: Sejarah Seksualitas. Jakarta: Yayasan Obor Indonesia bekerja sama dengan Fakultas Ilmu Budaya Universitas Indonesia dan Forum Jakarta-Paris.

Hewitt, K. (1995). “Sustainable Disasters? Perspectives and Powers in the Discourse of Calamity." Dalam Power of Development, disunting oleh J. Crush, 111-123. London dan New York: Routledge.

Hidayat, F. dan I. Rudiarto. (2013). "Pemodelan Resiko Banjir Lahar Hujan pada Alur Kali Putih Kabupaten Magelang." Jurnal Teknik PWK Vol. 2 No. 4, hlm. 895-904.

Indonesian Society for Social Transformation (INSIST). (2012). Perubahan Iklim dan Ketahanan Masyarakat di Empat Kabupaten di Indonesia (Kab. Merangin, Kab. Sinjai, Kab. Ende, dan Kab. Maluku Tenggara). Laporan penelitian. Tidak diterbitkan.

Jalin Merapi. (2010). “Warga Menginginkan Renovasi, Bukan Relokasi." (Online), (http:// merapi.combine.or.id/baca/10976/wargamenginginkan-renovasi--bukan-relokasi. html, diakses pada 20 September 2014)

. 2011. "Tolak Relokasi dan Perluasan TNGM, Sedumuk Bathuk Senyari Bumi Ditohi Pati Menjadi Pekik Warga Kalitengah.". (Online), (http://merapi. combine.or.id/baca/13303/tolak-relokasidan-perluasan-tngm-sedumuk-bathuksenyari-bumi-ditohi-pati-menjadi-pekikwarga-kalitengah.html, diakses pada 20 September 2014)

James, E. (2008). “Getting ahead of the Next Disaster: Recent Preparedness Efforts in Indonesia." Development in Practice 18 (3): 424-429.
Jha, A.K., dengan J.D. Barenstein, P.M. Phelps, D. Pittet, danS.Sena. (2010). Safer Homes, Stronger: Communities: A Handbook for Reconstructing after Natural Disasters. Washington, D.C.: The International Bank for Reconstruction and Development dan The World Bank.

Kedaulatan Rakyat. (2012). “Warga Watugajah Mulai Melunak." (Online), (http://krjogja. com/read/131320/warga-watugajah-mulaimelunak.kr, diakses pada 2 Juni 2013) . 2012. “20 Rumah Baru Berdiri di Watugajah." (Online), (http://krjogja.com/ $\mathrm{read} / 149881 / 20$-rumah-baru-berdiri-diwatugajah.kr, diakses pada 2 Juni 2013)

Kompas. (2012). "1.076 Keluarga Menolak Relokasi dari Zona Rawan Bencana." (Online), (http://megapolitan.kompas. com/read/2012/10/22/03040876/1.076. Keluarga.Menolak.Relokasi.dari.Zona.Raw an.Bencana, diakses pada 2 Juni 2013)

.2012. “Menolak Relokasi, Risiko Tanggung Sendiri." (Online), (http://cetak.kompas. com/read/2012/10/25/03011956/Menolak. Relokasi..Risiko.Tanggung.Sendiri, diakses pada 2 Juni 2013)

Kusumasari, B. dan Q. Alam. (2012). “Local Wisdom-Based Disaster Recovery Model in Indonesia." Disaster Prevention and Management 21 (3): 351-369.

Layang PRB. (2012). "Huntap Diharapkan Selesai Akhir 2012." Oktober-November.

Li, T.M. (2005). "Beyond 'the State' and Failed Schemes." American Anthropologist 107 (3): 383-394.

. 2007. "Governmentality." Anthropologica 49: 275-294.

McKee, K. (2009). “Post-Foucauldian Governmentality: What Does It Offer Critical Social Policy Analysis?" Critical Social Policy 29 (3): 465-486.

Oliver-Smith, A. (2002). “Displacement, Resistance and the Critique of Development: From the Grass-Roots to the Global." RSC Working Paper No. 9. Oxford: Refugee Studies Centre, University of Oxford. 
Putro, S.H. (2011). “Dampak Bencana Aliran Lahar Dingin Gunung Merapi Pasca Erupsi di Kali Putih." Makalah dalam Seminar Nasional “Pengembangan Kawasan Merapi: Aspek Kebencanaan dan Pengembangan Masyarakat Pasca Bencana" di Fakultas Teknik Sipil dan Perencanaan (FTSP), Universitas Islam Indonesia, Yogyakarta, 8 Maret.

Ribot, J. (2010). “Vulnerability Does Not Fall from the Sky: Toward Multiscale, Pro-Poor Climate Policy." Dalam Social Dimensions of Climate Change: Equity and Vulnerability in a Warming World, disunting oleh R. Mearns dan A. Norton, 47-74. Washington, D.C.: World Bank.

Rose, N. (2004). Powers of Freedom: Reframing Political Thought. Cambridge: The Press Syndicate of the University of Cambridge. P. O'Malley, dan M. Valverde. (2006). "Governmentality." Annual Review of Law and Social Science 2: 83-104.

Saragih, B., L. Ni'am, N. Sirimorok, P. Yunifa, dan S. Abdullah. (2014). Asmaradana Merapi: Narasi Ketangguhan Orang-Orang Merapi. Jakarta: Badan Nasional Penanggulangan Bencana (BNPB) dan United Nations Development Programme (UNDP) Indonesia.

Seputar Indonesia. (2012). "Warga Korban Merapi Tolak Relokasi." (Online), (www. seputar-indonesia.com/edisicetak/content/ view/497461/, diakses pada 2 Juni 2013) . (2012). “166 KK di Watugajah Tolak Hunian Tetap.” (Online), (www.seputar-indonesia. com/edisicetak/content/view/529227/, diakses pada 2 Juni 2013

Sekretariat Multi Donor Fund untuk Aceh dan Nias dan Java Reconstruction Fund. (2012). Rekompak: Membangun Kembali Masyarakat Indonesia Pascabencana. Jakarta: Bank Dunia.

Sindonews. (2012). “1.076 Keluarga Tetap Menolak Relokasi.” (Online), (http://daerah. sindonews.com/read/682368/22/1-076keluarga-tetap-menolak-relokasi, diakses pada 30 September 2014)

Sliwinski, A. (2010). “The Politics of Participation: Involving Communities in Post-Disaster Reconstruction." Dalam Rebuilding after Disasters: From Emergency to Sustainability, disunting oleh G. Lizarralde, C. Johnson, dan C. Davidson, 177-192. London dan New York: Spon Press.

Suara Merdeka. (2011). “Dusun Watugajah Kemungkinan akan Direlokasi." (Online), (http://www.suaramerdeka.com/v1/index. php/read/news/2011/01/07/74902/DusunWatugajah-Kemungkinan-akan-Direlokasi, diakses pada 2 Juni 2013)

. (2012). “Penerima Huntap Jangan Takut Tanahnya Diambil Negara." (Online), (http:// www.suaramerdeka.com/v1/index.php/ $\mathrm{read} /$ news/2012/02/08/108984/PenerimaHuntap-Jangan-Takut-Tanahnya-DiambilNegara, diakses pada 2 Juni 2013)

. (2012). "Warga Watugajah Menolak Direlokasi." (Online), (http://www. suaramerdeka.com/v1/index.php/read/ news/2012/04/30/117012/Warga-WatugajahMenolak-Direlokasi, diakses pada 2 Juni 2013)

Tierney, K. (2012). “Disaster Governance: Social, Political, and Economic Dimensions." Annual Review of Environment and Resources 37: 341-363.

Tribunnews. (2012). “Warga Dusun Watugajah Menolak Relokasi." (Online), (http://www. tribunnews.com/regional/2012/05/23/ warga-dusun-watugajah-menolak-relokasi, diakses pada 30 September 2014)

Twigg, J. (2009). Characteristics of DisasterResilient Community: A Guidance Note. London: Latitude.

Wisner, B., P. Blaikie, T. Cannon, dan I. Davis. (2004). At Risk: Natural Hazards, People's Vulnerability and Disasters. New York: Routledge. 